\title{
Utilizing Human Remains for Science: Ethical, Legal, and Scientific Issues in Croatia, United Kingdom and the United States
}

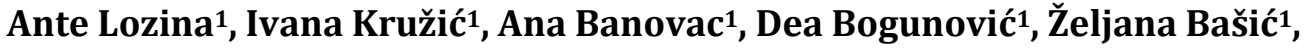 \\ Irina Zakirova², James Rayner ${ }^{3}$, Martin Smith ${ }^{3}$ \\ ${ }^{1}$ University Department of Forensic Sciences, University of Split, Split, Croatia \\ ${ }^{2}$ Department of Law, Police Science and Criminal Justice Administration, John Jay College of Criminal Justice/CUNY, New York, \\ USA \\ ${ }^{3}$ Department of Archaeology and Anthropology, Bournemouth University, Bournemouth, United Kingdom \\ Email: ante.lozina@unist.hr,i7468638@bournemouth.ac.uk
}

How to cite this paper: Lozina, A., Kružić, I., Banovac, A., Bogunović, D., Bašić, Ž., Zakirova, I., Rayner, J., \& Smith, M. (2021). Utilizing Human Remains for Science: Ethical, Legal, and Scientific Issues in Croatia, United Kingdom and the United States. Beijing Law Review, 12, 161-176. https://doi.org/10.4236/blr.2021.121009

Received: January 15, 2021

Accepted: March 16, 2021

Published: March 19, 2021

Copyright $\odot 2021$ by author(s) and Scientific Research Publishing Inc. This work is licensed under the Creative Commons Attribution International License (CC BY 4.0).

http://creativecommons.org/licenses/by/4.0/

\begin{abstract}
The study of human remains has a significant impact on the present society. They are utilized in research, in fields studying the human past and origins, in epidemiology, the study of anatomy and morphology, pathology and trauma, and form a part of museum exhibits. On the other hand, they are significant to various groups in cultural, religious, spiritual, and personal ways. Therefore, these factors should be considered when conducting research. Although some countries ensure legal protection of human remains, usually, such concerns usually cover remains that are younger than 100 years. The differences between countries in legal protections and also the cultural, religious, and ethical attitudes that underlie them can hinder international cooperation. The current collaborative research study sought to investigate and compare such differences between Croatian, United Kingdom's and United States' approach to the study of human remains encompassing the following: definitions of human remains as cultural goods, legal issues with obtaining custody over the body parts, compensations for the next of kin for the use of human remains for science, and public perceptions about obtaining body parts for scientific purposes through cultural and religious aspects in perspective with religious beliefs, education, place of origin, gender and attitudes towards science. After collecting data and determining all the above mentioned factors, our aim is to propose the policies on utilizing human remains on multilateral/international level (especially regarding human remains in museums and related institutions) through guidelines, taking into account the differences in ethnicity, religion and degree of formal education between social groups in different countries.
\end{abstract}




\section{Keywords}

Human Skeletal Remains, Religion, Heritage, Legal Issues, Cultural Differences, Ethical Issues

\section{Introduction}

\subsection{The Lack of Internationally Applicable Framework Regarding Human Skeletal Remains}

We have examined existing legal and ethical frameworks regarding human remains from three countries with different legislatures, cultures, distribution of religions, history, and customs. Every country has focused its efforts on dealing with human remains through contexts relevant to its particular history (Homeland War in Croatia, reparations in the UK and Native Americans, Native Hawaiians, and early colonial period in the USA) (Šlaus, Novak, \& Vodanović, 2011; Ubelaker Douglas, 2011). Currently, there is a lack of international regulations that would oversee the utilization of human remains for scientific purposes. An international framework is essential for scientific research involving international cooperation, including the transportation of human remains through different countries and continents, in cases of reparations, etc. Because of different legislative, different religious distribution of the populations, and different historical (usually unresolved) issues, every country has different views on how, when, how long, in which manner, by whom, etc. human remains should be handled. Thus, international cooperation can be restricted or even compromised since there is no international legislative that is legally or ethically superior to the legislative of an individual country (Márquez-Grant \& Fibiger, 2011).

The international framework should be developed in a way that its guidelines are acceptable to all parties included, regardless of legislative, ethics, religion, history, or customs of specific countries.

\subsection{Practice Regarding Human Skeletal Remains in Croatia}

The first stages of development of biological anthropology research in Croatia took off in the second half of the $19^{\text {th }}$ century and lasted until the mid $20^{\text {th }}$ century. This period was characterized by the scientific work conducted mostly by foreign researchers of various expertise backgrounds, with exceptions of Croatian experts such as Dragutin Gorjanović Kramberger, who conducted paleoarcheological research and archeological excavations of Neanderthals in Krapina. The second period of development of biological anthropology in Croatia started after World War II with Croatian anthropologists as investigation leaders. The start of the latest period of biological anthropology in Croatia was boosted by implementation of modern scientific methods and knowledge in identifying the victims of the Homeland War (Rajić Šikanjić, 2005; Šlaus, 2006).

Some of the leading institutions in the development of bio-anthropology and 
bioarchaeology in Croatia are the Institute of Anthropology, Department of Archaeology at the University of Zagreb, the Institute for Archaeology in Zagreb, the Clinical Department of Pathology, Forensic Medicine and Cytology at the University Hospital Center in Split, the University Department of Forensic Sciences at the University of Split, the Department of Dental Anthropology at the School of Dental Medicine, University of Zagreb, and the Department of Archaeology at the Croatian Academy of Sciences and Arts. There are three osteological collections in Croatia. The largest osteological collection is located in Zagreb, at the Department of Archaeology at the Croatian Academy of Sciences and Arts, and contains over 5500 skeletons from various historical periods (Šlaus, Novak, \& Vodanović, 2011). The other skeletal collection is in Split, at the University Department of Forensic Sciences, which contains more than 3000 skeletal remains dating from prehistoric to the modern period. There is also an ossuary located in Mirogoj cemetery in Zagreb, which contains skeletal remains of unidentified World War II, post-World War II, and Homeland War victims (Ministry of Croatian Veterans' affairs, 2020).

Croatian legislative framework does not stipulate legal provisions regarding human osteological remains in the narrow sense. It instead refers to them as a part of a broader context, such as "cultural goods," "cultural heritage," "archaeological findings," etc. Some of the laws and regulations dealing with human remains in a broader context are Law on Protection and Conservation of Cultural Property (COG 69/99, 62/20), Regulations on Archaeological Research (COG 102/10, 2/20), Law on Application of Human Tissue and Cells (COG 144/12), Law on Cemeteries (COG 19/98, 89/17), and Law on Research, Planning and Maintenance of Military Cemeteries, WWII Victims and Post WWII Victims Cemeteries (COG 143/12). Law on Protection and Conservation of Cultural Property (COG 69/99, 62/20) determines all different kinds of cultural goods and cultural heritage, measures of their protection and preservation, as well as the financing of those measures. Although human skeletal remains are not explicitly mentioned, this Law defines cultural goods as movable or unmovable objects of historical, anthropological, archaeological and scientific significance or archaeological sites that testify about human presence during different periods that have historical and anthropological value, which gives us clear indication that these broader terms incorporate the terms related to human osteological material (COG 69/99, 62/20).

Regulations on Archaeological Research (COG 102/10, 2/20) lays down conditions for carrying out archaeological research in Croatia, including sites with human skeletal material, which are not explicitly listed. Law on Application of Human Tissue and Cells (COG 144/12) determines the conditions of collection, removal, testing, processing, preservation, storage, distribution and application of human tissues and cells, including those of living and deceased people, which is a clear indicator that there is no close relationship with processing human osteological remains from archaeological sites. Law on Cemeteries (COG 19/98, 89/17) provides conditions for construction, usage, and management of the gra- 
veyards with minimal mention of deceased people or their respective remains. On the other hand, Law on Research, Planning and Maintenance of Military Cemeteries, WWII Victims and Post WWII Victims Cemeteries (COG 143/12) stipulates regulations for the treatment of remains of people who perished in the war conflicts during last century and provides conditions for research, excavations, reburial, and other practices regarding osteological remains of war victims.

There are no stipulated ethical guidelines in Croatia concerning the questions of utilizing human remains for science. The International Council of Museums (ICOM) Code of Ethics for Museums has been implemented in Croatia as a reference for the practice of museum professionals.

\subsection{Practice Regarding Human Skeletal Remains in the UK}

The United Kingdom has a long and rich history of collecting and curating human skeletal remains. There are numerous osteological collections in the United Kingdom, of which key examples include: The Royal College of Surgeons of England in London, Duckworth Collection in Cambridge, Human Skeletal Collection of Forensic Anthropology Laboratory in the University of Lincoln, The Fenwick Human Osteology Collection in Durham, Human remains collection in Edinburgh, Skeletal Teaching Collection Dundee, and Anatomical Collection Aberdeen (Forensic Anthropology Society of Europe, 2018).

Regulations of dealing with human remains, including human skeletal remains, are covered under the Human Tissue Act of 2004 (Price, 2005), which regulates the storage, removal, and use of human remains. The Department of Culture, Media and Sport's Guidance for the care of human remains in museums in England and Wales is also an important guide on lawful acquirement and treatment of human remains. This document raises questions regarding legal issues in caring for human remains, decisions to de-accession human remains, sets an ethical framework through procedural responsibilities, ethical principles, and gives procedural guidance in case of claims for the return of human remains (Swain, 2005). This document sets an example of good practice in handling human remains.

Taking into consideration United Kingdom's long colonial past, there are several ethical issues regarding relations to osteological remains of certain ethnic groups, such as those of indigenous populations of formerly colonial territories (Sayer, 2010).

\subsection{Practice Regarding Human Skeletal Remains in the USA}

Excavation and analysis of human remains and associated artifacts found in the USA mostly concern material related to the Native Americans, post-contact Europeans, formerly enslaved Africans, and Native Hawaiians. Human remains of indigenous descent have been the subject of considerable controversy due to the nature of their customs, spirituality, and religious beliefs. According to Native American traditions and Native Hawaiian beliefs, skeletal remains and other ar- 
tifacts must remain buried in cases of excavation reburied on the exact location of their finding, otherwise, the souls of the human remains are disturbed (Bowman, 1989). Historically, Native Americans reservations are a separate entity recognized by the federal government since they existed before the US Constitution was ratified (Tsosie, 2000). Hawaii, which was last to become a state in the US, had its own federally approved statute that dealt with discovered human remains prior to the Native American Grave Protection and Repatriation Act (NAGPRA) (Russo, 2010).

Earliest cited research (Eggan, 1937), (Eggan, 1955), (Trigger, 1980) indicate that anthropologists had a vast interest in the research of the Native Americans, and often regarded their burial sites open for study thus disregarding the Native Americans' traditions and beliefs, which was later scrutinized. By the 1990s, the public perception shifted towards the idea that research cannot be conducted without respecting the rights of the people whose history is being studied (Hibbert, 1998). Lack of legislation on protection of Native American lands as well as ineffective enforcement of the existing regulations allowed archeologists or other individuals to illegally excavate human remains and artifacts from reservations, thereby adding to the trafficking of human remains. Therefore, scientists and indigenous people sought to establish general ethical guidelines related to studying native history (Fixico, 1996).

In 1990 the Federal government passed the NAGPRA, a federal act that seeks criminal penalties for illegally excavating, selling, and trafficking the artifacts found on the native lands or reservations (McManamon, 2000). NAGPRA was a significant leap towards addressing the concerns of the tribal communities, as well as their traditions and beliefs regarding the human remains. More specifically, with the introduction of NAGPRA, the indigenous people could now seek the repatriation and reburial of the human remains that were excavated on their lands.

Prior to NAGPRA, Hawaii followed the Hawaii Revised Statutes 6-E under the Department of Land and Natural Resources. Hawaii founded a Hawaiian national museum overseeing the care of all human remains and artifacts found on the private or public lands. The museum worked along with burial treatment councils, which determined whether the discovered remains should be sent to the museum or left where they were found. After the enactment of NAGPRA, the Hawaiian National museum went under its jurisdiction since it was federally funded and to date adheres to NAGPRA (Russo, 2010).

However, some examples are supporting the claim that NAGPRA has not been fully enforced (National Congress of American Indians, 2019). The excavators still violate the law and secretly visit the burial sites to excavate the remains or other artifacts. Also, data from sites like eBay gave insight into people posting skeletal remains and artifacts for sale (Halling \& Seidemann, 2016). To date, nearly 30 states introduced some form of protection of human remains found and excavated on private or state-owned lands (Washington College of 
Law, 2019). However, the introduction of the laws does not guarantee appropriate and respectful treatment human remains if the laws are not implemented in a timely and systematic manner.

One of the most prominent examples of NAGPRA being enforced is in the case of the Kennewick Man (1996) since it pointed to NAGPRA's major weakness (Kelly, 1999). The Native Americans requested the return of a male body found in Washington, dated more than 9000 years. Even though they were unable to prove their cultural affiliation to the remains, they claimed that since Native Americans are considered the eldest US territory population, the body was likely to have been a Native American. In 2005, Senator McCain amended NAGPRA and sought the return of the remains to Native Americans (Weimer, 2005). However, a group of scientists filed a claim in the federal district court who overturned the decision. In the end, only in 2017, the Kennewick Man, with Senate's approval, was returned to the tribes where he was finally buried (Burke Museum, 2021).

The study of human remains is significant as it allows society to learn about the lifestyles of previous generations. Historically, colonists' human remains are spread throughout many states in the USA, and were found in places such as Jamestown, Virginia (2015), the discovery of one of the colonies to settle in the US dating from 1607 (Fandos, 2015); St. Augustine, Florida (2017), the discovery of remains that were buried under a church and is a colonial settlement dating from 1586. The archeologists were given ample amount of time to scientifically examine the remains and get a more detailed overview of the lifestyle of the first colonial settlements.

To accommodate the interests of all parties, Native Americans, Native Hawaiians, archeologists, and scientists, the federal government amended NAGPRA's sections 5 - 7. The act requires federally funded museums, and researchers to conduct inventories on remains or artifacts that may belong to the Native Americans or Native Hawaiians as well as to reach a consensus about the future of the remains (McManamon, 2000). Besides a federal regulation, states such as California, have implemented a California Native American Graves Protection and Repatriation Act of 2001. The goal of the act is to build a consensus between the Native Americans and the research community (Rothman, 2017). As a result, in 2018, an amendment to the act was ratified which initiated committees that will oversight such relationship as well as find solutions to conflicts between the two parties of interest (Assembly Bill 2836, 2018).

Considering the above, the purpose of this study is to examine public attitudes about handling human remains by research institutions and museums in the USA, Croatia, and the UK. Collected responses will allow narrowing a list of essentials that should be included in international guidelines in utilizing human remains for science.

\section{Materials and Methods}

Two types of the survey were conducted in three countries: US, New York City 
(paper-format survey), UK, general population (online survey) and Croatia, University of Split students (online survey) during 2018. Due to language barriers, questions for Croatian participants were translated to Croatian. The sample was a convenience sample, and it included 250 participants from the USA, 157 from the UK, and 140 from Croatia. The purpose of conducting the survey was to explore the nature and extent of differences in attitudes and opinions between three example countries in order to inform considerations of how an international framework might be reached. The questions were divided into two parts. The first part included general questions such as the participants' gender, age, education level, religion/spirituality place of origin, and household income. The second part of the survey consisted of questions regarding the attitudes about the handling of and scientifically researching human remains, museum display, and popularization of the science using human skeletal remains. The opinions were measured using a Likert scale, ranked from 1 - 5, where 1 was defined as strongly disagree and 5 as strongly agree.

The lack of this study is the disparity in some of the study questions, as the Bournemouth study was conducted earlier than the two other surveys.

\subsection{Statistical Methods}

Demography of the participants was presented as frequencies and percentages. Specifically, age was given as a median with $95 \%$ CI. Differences between the participant groups' opinions were tested by comparing means with one-way ANOVA, and the descriptive statistics were used to compare the demographic data.

All analysis was conducted using SPSS (version 18; SPSS Inc, Chicago, IL, USA), with the significance level set at $P<0.05$.

\subsection{Results}

The survey was completed by 140 participants from Croatia, 250 from the USA, and 257 from the UK. The basic demographic data, along with the information on religion, spirituality, degree of formal education and field of study are presented in Table 1. Data obtained from all 3 conducted surveys provided the information on interconnections between degree of formal education, religion, spirituality and views on scientific research of human skeletal remains.

The three countries differed significantly in spirituality $\left(\chi^{2}=208.38, P<\right.$ $0.001)$, place of origin $\left(\chi^{2}=40.01, P<0.001\right)$, the highest degree $\left(\chi^{2}=289.97, P<\right.$ $0.001)$. Additionally, participants' responses differed in household income $\left(\chi^{2}=\right.$ 28.06, $P<0.001)$ and in the field of study $\left(\chi^{2}=191.69, P<0.001\right)$.

This part of the survey was intended to give the insight on peoples' attitude toward utilizing human remains in scientific context, and to examine views on using human skeletal material for purposes of popularization of science, education and displaying them in museums and related institutions. The results from this part of the survey are presented in Table 2. 
Table 1. Demography data on Croatian, UK, and US participants.

\begin{tabular}{|c|c|c|c|c|}
\hline & & Croatia & UK & USA \\
\hline \multirow[t]{4}{*}{ Gender } & Male & $42(30.00 \%)$ & $121(47.08 \%)$ & $126(50.40 \%)$ \\
\hline & Female & $97(69.29 \%)$ & $134(52.14 \%)$ & $124(49.60 \%)$ \\
\hline & Non-binary & $1(0.71 \%)$ & $2(0.78 \%)$ & I \\
\hline & Total & 140 & 257 & 250 \\
\hline \multirow[t]{4}{*}{ Median age \pm SD } & Male & $29(19-47)$ & $21(14-76)$ & $27(18-45)$ \\
\hline & Female & $24(19-60)$ & $22(16-76)$ & $19(18-44)$ \\
\hline & Non-binary & I & $22.5(20-25)$ & I \\
\hline & Total & $25(19-60)$ & $22(14-76)$ & $24(18-45)$ \\
\hline \multirow[t]{3}{*}{ Place of origin } & Less than 10,000 inhabitants & $47(33.57 \%)$ & $58(22.48 \%)$ & $36(15.00 \%)$ \\
\hline & $10,000-100,000$ inhabitants & $32(22.56 \%)$ & $115(44.57 \%)$ & $75(31.25 \%)$ \\
\hline & More than 100,000 inhabitants & $61(43.57 \%)$ & $85(39.95 \%)$ & $129(53.75 \%)$ \\
\hline \multirow[t]{3}{*}{ Household income } & Below average & $6(4.29 \%)$ & I & $63(25.71 \%)$ \\
\hline & Average & $106(75.71 \%)$ & I & $148(60.40 \%)$ \\
\hline & Above average & $28(20.00 \%)$ & l & $34(13.89 \%)$ \\
\hline \multirow{8}{*}{$\begin{array}{l}\text { The highest degree } \\
\text { completed }\end{array}$} & High school and lower & l & $160(62.26 \%)$ & l \\
\hline & Professional degree & $4(2.96 \%)$ & l & l \\
\hline & Professional bachelor degree & $4(2.96 \%)$ & l & l \\
\hline & Postgraduate specialist degree & $2(1.48 \%)$ & l & l \\
\hline & Bachelor degree & $19(14.07 \%)$ & $73(28.40 \%)$ & $229(91.97 \%)$ \\
\hline & Master degree & $83(61.48 \%)$ & $16(6.23 \%)$ & $20(8.03 \%)$ \\
\hline & Integrated degree & $5(2.04 \%)$ & l & l \\
\hline & Doctorate degree & $18(13.33 \%)$ & $8(3.11 \%)$ & l \\
\hline \multirow[t]{3}{*}{ Field of study } & STEM & $58(43.61 \%)$ & l & $15(6.10 \%)$ \\
\hline & Arts, social sciences and humanities & $34(25.56 \%)$ & l & $231(93.90 \%)$ \\
\hline & Interdisciplinary sciences & $41(30.83 \%)$ & / & l \\
\hline \multirow[t]{11}{*}{ Religion } & Roman Catholicism & $114(83.21 \%)$ & $15(5.84 \%)$ & $78(31.71 \%)$ \\
\hline & Orthodox & $1(0.73 \%)$ & / & $3(1.22 \%)$ \\
\hline & Hinduism & $1(0.73 \%)$ & I & $2(0.81 \%)$ \\
\hline & Atheist/Agnostic & $21(15.33 \%)$ & $208(80.93 \%)$ & $50(20.33 \%)$ \\
\hline & Christianity & I & $18(7.00 \%)$ & $67(27.24 \%)$ \\
\hline & Judaism & I & $2(0.78 \%)$ & $6(2.44 \%)$ \\
\hline & Anglican & I & $1(0.39 \%)$ & I \\
\hline & Pagan & I & $2(0.78 \%)$ & $1(0.41 \%)$ \\
\hline & Church of England & I & $6(2.33 \%)$ & I \\
\hline & Buddhism & I & $1(0.39 \%)$ & $7(2.85 \%)$ \\
\hline & Episcopal & I & $1(0.39 \%)$ & I \\
\hline
\end{tabular}




\section{Continued}

\begin{tabular}{|c|c|c|c|c|}
\hline & Presbyterian & l & $1(0.39 \%)$ & l \\
\hline & Protestant & l & $2(0.78 \%)$ & l \\
\hline & Islam & l & l & $14(5.69 \%)$ \\
\hline & Scientology & I & I & $1(0.41 \%)$ \\
\hline & Baptism & l & l & $1(0.41 \%)$ \\
\hline & Mormon & l & l & $1(0.41 \%)$ \\
\hline & Sikhism & I & I & $3(1.22 \%)$ \\
\hline & Other & l & I & $12(4.88 \%)$ \\
\hline Spirituality & Not religious/but spiritual & $30(21.43 \%)$ & $64(24.90 \%)$ & $66(26.51 \%)$ \\
\hline & Not religious/not spiritual & $15(10.71 \%)$ & $154(59.92 \%)$ & $50(20.08 \%)$ \\
\hline & Religious/spiritual & $74(52.86 \%)$ & $18(7.00 \%)$ & $56(22.49 \%)$ \\
\hline & Religious/not spiritual & $21(15.00 \%)$ & $21(8.17 \%)$ & 77 (30.92\%) \\
\hline
\end{tabular}

Table 2. Personal attitudes toward usage and handling of human remains in scientific institutions and museums.

\begin{tabular}{|c|c|c|c|}
\hline Statement & $\begin{array}{l}\text { Croatia (Mean, } 95 \% \\
\text { confidence interval) }\end{array}$ & $\begin{array}{l}\text { USA (Mean, } 95 \% \\
\text { confidence interval) }\end{array}$ & $P$ \\
\hline \multicolumn{4}{|l|}{ Affirmative statements } \\
\hline It is appropriate to use human burials and bones for science popularization and education & $4.28(4.06-4.50)$ & $3.53(3.38-3.69)$ & $<0.001$ \\
\hline $\begin{array}{l}\text { Displaying human burials and bones in a museum appeals to sensationalism rather than } \\
\text { intellectual curiosity }\end{array}$ & $3.01(2.82-3.21)$ & $3(2.84-3.16)$ & 0.912 \\
\hline $\begin{array}{l}\text { Keeping human bones for research purposes helps us to find out more about how people } \\
\text { lived in the past }\end{array}$ & $4.37(4.21-4.54)$ & $4.33(4.19-4.47)$ & 0.726 \\
\hline $\begin{array}{l}\text { Keeping human bones in museums for research purposes helps us to find out more } \\
\text { about the disease and find better treatments or cures }\end{array}$ & $4.19(4.04-4.35)$ & $3.88(3.72-4.03)$ & 0.014 \\
\hline $\begin{array}{l}\text { Displaying human burials and bones in a museum helps us to come to terms with our } \\
\text { own mortality }\end{array}$ & $2.99(2.78-3.21)$ & $3.33(3.15-3.50)$ & 0.015 \\
\hline $\begin{array}{l}\text { The religion of buried individual should be taken into account while dealing with human } \\
\text { burials and bones }\end{array}$ & $3.36(3.14-3.58)$ & $4.04(3.86-4.22)$ & $<0.001$ \\
\hline \multicolumn{4}{|l|}{ Negative statements } \\
\hline Human burials and bones cannot help in any of future scientific research & $1.60(1.42-1.77)$ & $2.22(2.03-2.42)$ & $<0.001$ \\
\hline Keeping human bones for research purposes does not produce any useful knowledge & $1.52(1.35-1.68)$ & $2.21(2.03-2.39)$ & $<0.001$ \\
\hline It is inappropriate to use human burials and bones for future scientific research & $1.71(1.51-1.90)$ & $2.67(2.48-2.87)$ & $<0.001$ \\
\hline Using human burials and bones for scientific research shows a lack of respect to the dead & $1.94(1.73-2.15)$ & $2.88(2.69-3.07)$ & $<0.001$ \\
\hline $\begin{array}{l}\text { Displaying and keeping human burials and bones in a museum shows a lack of respect to } \\
\text { the dead }\end{array}$ & $2.11(1.90-2.32)$ & $3.88(3.72-4.04)$ & $<0.001$ \\
\hline
\end{tabular}

Although UK participants did not have the same questionnaire for this part as the USA and Croatia did, some of the questions could be compared.

For the question: Do you think it is appropriate to use skeletons for education and popularization of science? A total of $93.8 \%$ of participants answered positively. 
For the question: Should the religion of a buried individual affect the treatment of human remains? $56.4 \%$ of the participants answered positively.

$61.4 \%$ (86/140) Croatian participants answered to statement: Museums should be allowed to display human bones as long as this is done sensitively; that they agree regardless of how old the bones are. Also, their answer for the statement: Museums and laboratories should be allowed to keep human bones for research purposes as long as this is done sensitively, in number $99 / 140$ (70.7\%) of cases was that they agree regardless of how old the bones are.

53.6\% (134/250) USA participants answered to statement: Museums should be allowed to display human bones as long as this is done sensitively; that they agree regardless of how old the bones are. Also, their answer for the statement: Museums and laboratories should be allowed to keep human bones for research purposes as long as this is done sensitively, in number 150/250 (60\%) of cases was that they agree regardless of how old the bones are.

The participant answers about their attitudes towards science, scientific research, and progress are shown in Table 3.

There was a statistically significant difference between three countries for the question: Investing in science is a key to free and prosperous society $(P=0.034)$. Croatia and USA did not differ $(P=0.490)$, USA, and UK did differ $(P=0.011)$, and Croatia and UK did not differ $(P=0.092)$.

There was a statistically significant difference between the three countries for the question: Science helps to make life better $(P=0.015)$. The Croatia and USA

Table 3. Personal attitudes toward science, scientific research, and progress.

\begin{tabular}{|c|c|c|c|}
\hline Statement & $\begin{array}{l}\text { Croatia (Mean, } \\
95 \% \text { confidence } \\
\text { interval) }\end{array}$ & $\begin{array}{l}\text { UK (Mean, 95\% } \\
\text { confidence } \\
\text { interval) }\end{array}$ & $\begin{array}{l}\text { USA (Mean, } \\
\text { 95\% confidence } \\
\text { interval) }\end{array}$ \\
\hline \multicolumn{4}{|l|}{ Affirmative statements } \\
\hline $\begin{array}{l}\text { Investing in science is key to a free and } \\
\text { prosperous society }\end{array}$ & $4.19(4.00-4.38)$ & $4.38(4.26-4.50)$ & $4.10(3.91-4.29)$ \\
\hline Science helps to make life better & $4.42(4.25-4.59)$ & $4.41(4.30-4.52)$ & $4.20(4.03-4.36)$ \\
\hline I am curious about discoveries in science & $4.58(4.42-4.73)$ & $4.54(4.44-4.56)$ & $4.30(4.13-4.47)$ \\
\hline \multicolumn{4}{|l|}{ Negative statements } \\
\hline Money used on scientific projects is wasted & $1.64(1.48-1.80)$ & $1.59(1.48-1.70)$ & $2.33(2.14-2.52)$ \\
\hline Science is a man's worst enemy & $1.29(1.19-1.40)$ & $1.39(1.29-1.49)$ & $2.53(2.30-2.75)$ \\
\hline Science and religion are incompatible & $2.45(2.23-2.67)$ & l & $3.23(3.03-3.44)$ \\
\hline Scientists cannot be religious & $1.53(1.35-1.72)$ & I & $2.82(2.61-3.04)$ \\
\hline $\begin{array}{l}\text { Scientists should not conduct research that } \\
\text { God did not intend them to conduct }\end{array}$ & $1.75(1.54-1.96)$ & l & $2.87(2.63-3.11)$ \\
\hline $\begin{array}{l}\text { Generally speaking. modern science does } \\
\text { more harm than good }\end{array}$ & $1.99(1.76-2.22)$ & $1.77(1.64-1.91)$ & $2.91(2.70-3.11)$ \\
\hline $\begin{array}{c}\text { We rely too much on science and too little } \\
\text { on religion }\end{array}$ & $2.22(1.99-2.44)$ & $1.56(1.44-1.67)$ & $3.02(2.80-3.23)$ \\
\hline
\end{tabular}


did not differ $(P=0.077)$, USA and UK did differ $(P=0.030)$, and Croatia and UK did not differ $(P=0.928)$.

There was a statistically significant difference between three countries for the question: I am curious about discoveries in science $(P=0.015)$, and Croatia and the USA did differ $(P=0.031)$, USA and UK did differ $(P=0.017)$, and Croatia and UK did not differ $(P=0.718)$.

There was a statistically significant difference between three countries for the question: Money used on scientific projects is wasted $(P<0.001)$, and the Croatia and USA did differ $(P<0.001)$, USA and UK did differ $(P<0.001)$, and Croatia and UK did not differ $(P=0.652)$.

There was a statistically significant difference between three countries for the question: Science is a man's worst enemy $(P<0.001)$, and the Croatia and USA did differ $(P<0.001)$, USA and UK did differ $(P<0.001)$, and Croatia and UK did not differ $(P=0.213)$.

There was a statistically significant difference between the three countries for the question: Generally speaking, modern science does more harm than good ( $P$ $<0.001)$, and the Croatia and USA did differ $(P<0.001)$, the USA and UK did differ $(P<0.001)$, and Croatia and UK did not differ $(P=0.078)$.

There was a statistically significant difference between three countries for the question: We rely too much on science and too little on religion $(P<0.001)$, and the Croatia and USA did differ $(P<0.001)$, USA and UK did differ $(P<0.001)$, and Croatia and UK did differ $(P<0.001)$.

Opinions for statements: Science and religion are incompatible; Scientists cannot be religious, and Scientists should not conduct research that God did not intend them to conduct were all statistically significant $(P<0.001)$.

A separate set of questions was seeking public opinion about the legal side of utilizing human remains for scientific purposes. Specifically, for the question: Who should be taking care and protecting human skeletal remains, $50.6 \%$ of USA, 43.5\% Croatian and 30.2\% UK participants thought that the remains should be protected by State law/Federal law. 37.7\% of Croatian, $29.1 \%$ of UK and $69.4 \%$ of USA participants believed that the relatives of deceased should be protecting the remains. Additionally, 90.4\% USA, 91.2\% Croatian, and $79.2 \%$ of UK participants thought that there should be laws protecting the human skeletal remains. Therefore, $87 \%$ of Croatian and $90 \%$ of USA participants answered positively to question "Should the officials notify the public that human remains were found, etc.?" $89.2 \%$ of Croatian, $93.7 \%$ of USA participants answered positively to question "Should the proven relatives have right to choose if remains can be used for science?"

Participants' responses to the question, "Is it ethical for relatives to get compensation for allowing utilizing remains?" $71.4 \%$ of the USA, $63.5 \%$ of the UK, and $36.7 \%$ of Croatian participants answered positively. Overall, the three countries differed significantly $\left(\chi^{2}=45.86, P<0.001\right)$, whereas USA and UK did not differ $\left(\chi^{2}=3.58, P=0.058\right)$. 


\section{Discussion}

Considering the attitudes towards the usage and handling of the human bones, it seems that Croatia and the USA differed mostly in the statements considering the support to the scientific research on human remains. Considering the investments in research and development, the USA is in the top-ranked countries ( $2.7 \%$ of GDP), the UK (1.7\% of GDP). In comparison, Croatia has the lowest investment placed at $0.8 \%$ of GDP. Also, considering the number of scientists per million inhabitants, the USA has 4255, UK 4254, and Croatia only 1436 (UNESCO Institute for Statistics, 2018). So, the results of this comparison are unexpected. The difference among the countries is likely due to the inequality between the media's frequency of coverage and the construction of scientific discoveries. Specifically, it may be that the media does not provide enough information to the public about the necessity of scientific research because it does not fall into a popular topic category unless it discusses the negative aspects such as academic/scientific misconduct. As a result, there is currently a lack of popularization of scholarly works, which thereby go unnoticed by the general public.

In addition to that, the three countries were tested on their attitudes towards science. It was surprising that the three countries, when compared to each other, differed in all of the compared statements. However, when looking at the differences between the pairs of countries (e.g., Croatia vs. the USA, Croatia vs. the UK, and UK vs. the USA), some interesting data were obtained. For the negative statement, for three questions, there were no statistically significant differences between the UK and Croatia. At the same time, the USA differed both from Croatia and the UK. Also, for the three questions where the survey was not conducted in the UK, the USA and Croatia differed significantly. It seems that Croatian and UK have more trust in science than the USA participants do and that Croatians in comparison to USA participants are more favorable of seeing religion and science as compatible. The question that all the countries differed in was the question, "We rely too much on science and too little on religion." USA participants were indecisive (median 3.02), Croatians were in the middle with median 2.22, and UK participants strongly disagreed. UK population were mostly atheists, and not religious/not spiritual, which can explain the results. On the other hand, Croatians who were mostly Catholics and declared spiritual disagreed, but not strongly. Moreover, the USA population, with various religious and ambiguous answers about spirituality, agreed with this statement the most. When Croatia and USA were compared in the context of religion and the statement that religion of the buried individual should be taken into account while dealing with human burials and bones, they had statistically significant differences, which can point out that multi-religious societies are more sensitive towards the religious beliefs than those who are more homogenous. This is expectable since the USA is known to be a home for immigrants who come from various cultures and religious beliefs. In order to accommodate this type of society, the established social contract requires USA residents to be more tolerant 
of each other's religious beliefs.

Although Croatia, the USA, and the UK differed demographically and in the religious beliefs, as well as in the investments for science, they had similar attitudes towards the science and handling the human remains, so the reasons for the differences in the attitudes between the three countries should be found elsewhere. The UK is known by precisely developed guidelines about the work in the museums and handling human remains, and that could be the reason why their participants had positive attitudes about the science and handling human remains. Furthermore, the reasons for the UK and Croatian similarities could lie in the fact that these are both countries from the European continent and have similar heritage, despite the demographic, cultural, religious, and other differences. Although the UK has more science investments than Croatia, it seems that Croatians are open both to science and dealing with skeletal remains, which is not surprising as they had to face with identification of a large number of killed during the Homeland war in Croatia.

Meanwhile, in the USA, the central issue is not the funding for the scientific research of skeletal remains, but ancestral rights and guardianship of the found remains. Specifically, when it comes to Native Americans, especially American Indian populations and Hawaiians, the USA science researchers are eager to excavate and examine found remains, but their actions can conflict with the Native Americans' cultural beliefs, which, for instance, prohibit the excavation of the remains. Therefore, when it comes to creating international guidelines, it is essential to consider the population's demographics in order to accommodate not just the financial burden of research, but also the cultural beliefs of the society.

In terms of seeking legal protection and oversight over the human remains and its utilization for science, survey responses show that among the three countries, the participants, especially from the USA, strongly agree that there should be laws providing legal protection and oversight of the human remains. Additionally, participants seek such protection from the state/federal governments; noting that the USA provides federal protection; the participants, in this case, also seek it from the state and local governments. Therefore, compared to the UK and Croatia, USA participants gave significantly higher positive responses to this set of questions. Further, the USA and Croatia strongly believe that the government should notify the public about found human remains in order for the relatives to learn about them; in that if, the identified relatives want to take part in making the decisions along with the government about the future of the remains. All three countries varied about the statement on whether it is ethically correct for the relatives to receive compensation for allowing officials to use human remains for scientific purposes. USA respondents agreed with the statement the most, followed by UK and Croatia.

\section{Conclusion}

Conducted research provided us with insight on cultural, religious, ethical and 
other differences between societies and social groups in Croatia, UK and USA. The data obtained from conducted surveys will serve as a basis in creating international guidelines for handling human skeletal remains. Proposed guidelines should have a multidimensional frame dealing with ethical and legal issues. Popularization of the topic of utilizing human remains for scientific purposes (not just in schools but also in local communities to cover the population of all ages and social status) will be one of the pillars of proposed guidelines. The guidelines should be approachable for a wide category of people, outlining limitations, and ensure that all the populations' specifics have been taken into consideration. This will lead to more unified and predictable measures of utilizing human skeletal remains for scientific purposes in international terms, without losing sight of specific norms, customs and requirements in different social groups within different countries.

\section{Acknowledgements}

The authors would like to thank professors from John Jay College of Criminal Justice, New York: Gary Wright JD Esq., Dr. Mark Francis, Thomas Hyland, Joseph Williams, for agreeing to distribute the survey in their classrooms as well as special gratitude goes to Dean of Research Anthony Carpi and Director of Research Compliance Lynda Mules for support. The gratitude also goes to the Vice deans for Science of the University of Split, who helped in the survey dissemination among the students of the University.

\section{Disclaimer}

The attitudes and opinions expressed in this paper belong to the authors and do not necessarily have to be equal to those of their institutions.

\section{Conflicts of Interest}

The authors declare no conflicts of interest regarding the publication of this paper.

\section{References}

Assembly Bill 2836 (2018). 2018 Native Americans: Repatriation.

Bowman, M. B. (1989). The Reburial of Native American Skeletal Remains: Approaches to the Resolution of a Conflict. Harvard Environmental Law Review, 13, 147-208.

Burke Museum of Natural History \& Culture (2021). Kennewick Man/The Ancient One. https://www.burkemuseum.org/kennewickman

Eggan, F. (1937). Historical Changes in the Choctaw Kinship System 2. American Anthropologist, 39, 34-52. https://doi.org/10.1525/aa.1937.39.1.02a00040

Eggan, F. (1955). Social Anthropology of North American Tribes: Essays in Social Organization, Law, and Religion. Chicago, IL: University of Chicago Press.

Fandos, N. (2015). Unearthing Jamestown's Leaders, and a Mystery. https://www.nytimes.com/2015/07/29/us/remains-of-early-colonial-jamestown-leaders -are-identified.html 
Fixico, D. L. (1996). Ethics and Responsibilities in Writing American Indian History. American Indian Quarterly, 20, 29-39. https://doi.org/10.2307/1184939

Forensic Anthropology Society of Europe (2018). Osteological Collections. http://forensicanthropology.eu/osteological-collections

Halling, C. L., \& Seidemann, R. M. (2016). They Sell Skulls Online? A Review of Internet Sales of Human Skulls on eBay and the Laws in Place to Restrict Sales. Journal of Forensic Sciences, 61, 1322-1326. https://doi.org/10.1111/1556-4029.13147

Hibbert, M. (1998). Galileos or Grave Robbers? Science, the Native American Graves Protection and Repatriation Act, and the First Amendment. American Indian Law Review, 23, 425-458. https://doi.org/10.2307/20068890

Kelly, M. J. (1999). A Skeleton in the Legal Closet: The Discovery of Kennewick Man Crystalizes the Debate over Federal Law Governing Disposal of Ancient Human Remains. University of Hawai'i Law Review, 21, 41-72.

Law on Application of Human Tissue and Cells. Croatian Official Gazette, 144/12.

Law on Cemeteries. Croatian Official Gazette, 19/98, 50/12, 89/17.

Law on Protection and Conservation of Cultural Property. Croatian Official Gazette, NN $69 / 99,151 / 03,157 / 03,100 / 04,87 / 09,88 / 10,61 / 11,25 / 12,136 / 12,157 / 13,152 / 14,98 / 15$, $44 / 17,90 / 18,32 / 20,62 / 20$.

Law on Research, Planning and Maintenance of Military Cemeteries, Cemeteries of WWII and Post WWII Period Victims. Croatian Official Gazette, 143/12.

Márquez-Grant, N., \& Fibiger, L. (2011). The Routledge Handbook of Archaeological Human Remains and Legislation: An International Guide to Laws and Practice in the Excavation and Treatment of Archaeological Human Remains. Abingdon-on-Thames: Taylor \& Francis. https://doi.org/10.4324/9780203838716

McManamon, F. P. (2000). NPS Archeology Program: The Native American Graves Protection and Repatriation Act (NAGPRA). In L. Ellis (Ed.), Archaeological Method and Theory: An Encyclopedia (pp. 388-443). New York and London: Garland Publishing Co.

Ministry of Croatian Veterans' Affairs (2020). Missing Persons in Homeland War. https://branitelji.gov.hr/o-ministarstvu/djelokrug/mjere/nestale-osobe/nestale-osobe-u -domovinskom-ratu-834/834

National Congress of American Indians (2019). Cultural Protection \& NAGPRA. http://www.ncai.org/policy-issues/community-and-culture/cultural-protection-and-na gpra

Price, D. (2005). The Human Tissue Act 2004. The Modern Law Review, 68, 798-821. https://doi.org/10.1111/j.1468-2230.2005.00561.x

Rajić Šikanjić, P. (2005). Bioarchaeological Research in Croatia-A Historical Review. Collegium Antropologicum, 29, 763-768.

Regulations on Archaeological Research. Croatian Official Gazette, 102/10, 2/20.

Rothman, A. (2017). Well-Intentioned but Ineffective: A Legislative History of the California Native American Graves Protection and Repatriation Act, 2001. $\mathrm{PhD}$ Thesis, Oregon: University of Oregon.

Russo, J. M. K. (2010). How to Remedy the NAGPRA's Unintended Effect on Hawai'i after Brown v. Hawaii. Asian Pacific Law and Policy Journal, 12, 186-214.

Sayer, D. (2010). Ethics and Burial Archaeology, Duckworth Debates in Archaeology. London: Gerald Duckworth \& Co Ltd.

Šlaus, M. (2006). Bioarheologija. Zagreb: Školska knjiga. 
Šlaus, M., Novak, M., \& Vodanović, M. (2011). Croatia. In N. Márquez-Grant, \& L. Fibiger (Eds.), The Routledge Handbook of Archaeological Human Remains and Legislation: An International Guide to Laws and Practice in the Excavation and Treatment of Archaeological Human Remains (pp. 83-96). Abingdon-on-Thames: Taylor \& Francis.

Swain, H. (2005). Guidance for the Care of Human Remains in Museums. London: Department for Culture, Media and Sport.

Trigger, B. G. (1980). Archaeology and the Image of the American Indian. American Antiquity, 45, 662-676. https://doi.org/10.2307/280140

Tsosie, R. (2000). Land, Culture, and Community: Reflections on Native Sovereignty and Property in America. Indiana Law Review, 34, 1291-1312.

Ubelaker Douglas, H. (2011). United States of America. In N. Márquez-Grant, \& L. Fibiger (Eds.), The Routledge Handbook of Archaeological Human Remains and Legislation: An International Guide to Laws and Practice in the Excavation and Treatment of Archaeological Human Remains (pp. 533-542). Abingdon-on-Thames: Taylor \& Francis.

UNESCO Institute for Statistics (2018). How Much Does Your Country Invest in R\&D? http://uis.unesco.org/apps/visualisations/research-and-development-spending

Washington College of Law (2019). State Burials Law Project. https://www.wcl.american.edu/burial

Weimer, D. R. (2005). Native American Graves Protection and Repatriation Act (NAGPRA): Legal and Legislative Developments. Congressional Research Service-The Library of Congress. 